\title{
PENGUJIAN AKTIVITAS ANTIBAKTERI EKSTRAK KULIT RANTING SENGON (Falcataria moluccana) DENGAN PELARUT METANOL DAN N- HEKSANA
}

\author{
Nunik Tri Rahayu $^{1}$, Ai Sri Nurhasanah ${ }^{2}$, Alfi Rumidatul ${ }^{3 *}$, Feldha Fadhila ${ }^{4}$, Yayan Maryana ${ }^{5}$ \\ 1. Program Studi Teknologi Laboratorium Medik Institut Kesehatan Rajawali, Bandung-Indonesia \\ 2. Program Studi Teknologi Laboratorium Medik Institut Kesehatan Rajawali, Bandung-Indonesia \\ 3. Sekolah Ilmu dan Teknologi Hayati Institut Teknologi Bandung, Bandung-Indonesia \\ 4. Program Studi Teknologi Laboratorium Medik Institut Kesehatan Rajawali, Bandung-Indonesia \\ 5. Program Studi Farmasi Politeknik Meta Industri, Bandung-Indonesia
}

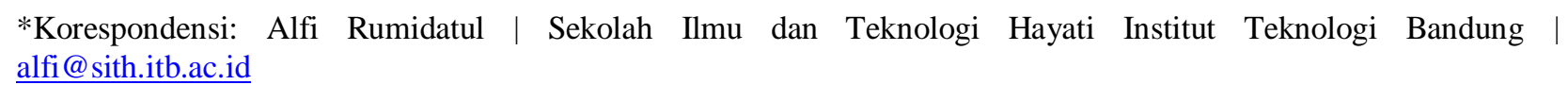

\begin{abstract}
Abstrak
Pendahuluan: Pohon Sengon (Falcataria moluccana) memiliki senyawa metabolit sekunder yaitu terpenoid, steroid, flavonoid, fenolik, tanin, saponin yang berfungsi sebagai antibakteri. Antibakteri bersumber dari alam menjadi alternatif untuk pengobatan penyakit infeksi. Penelitian ini bertujuan untuk mengetahui aktivitas antibakteri ekstrak kulit ranting Sengon dengan pelarut n-heksana dan metanol terhadap Shigella dysentriae, Klebsiella pneumoniae, Escherichia coli, Salmonella typhi, Staphylococcus aureus, Pseudomonas aeruginosa, dan Proteus mirabilis.

Metode: Penelitian ini menggunakan metode Kirby Bauer dengan konsentrasi ekstrak 9\%, 9,5\%, 10\%, 10,5\% dan $11 \%$.

Hasil: Hasil ekstrak kulit ranting Sengon menunjukkan adanya zona bening dengan konsentrasi efektif yaitu $11 \%$ terhadap Shigella dysentriae (4 mm), Escherichia coli $(1,7 \mathrm{~mm})$, Salmonella typhi $(3,3 \mathrm{~mm})$. Sedangkan ekstrak kulit ranting Sengon dengan pelarut n-heksana terhadap Proteus mirabillis $(2,7 \mathrm{~mm})$.

Kesimpulan: Ekstrak kulit ranting Sengon dengan pelarut metanol dan n-heksana memiliki aktivitas antibakteri terhadap Shigella dysentriae, Escherichia coli, Salmonella typhi, dan Proteus mirabilis.
\end{abstract}

Kata Kunci: Antibakteri, Falcataria moluccana, N-heksana, Metanol.

Diterima 23 Juli 2020; Accepted 30 Desember 2020

\section{PENDAHULUAN}

Penyakit infeksi merupakan jenis penyakit yang paling banyak diderita oleh penduduk negara berkembang, termasuk Indonesia. Penyakit infeksi dapat disebabkan oleh mikroorganisme patogen seperti bakteri, virus, parasit, atau jamur.

Perkembangan penyakit infeksi di Indonesia dapat dilihat dari beberapa data penyakit infeksi seperti pneumonia yang disebabkan oleh Klebsiella pneumoniae memiliki insiden 1,8\% dan prevalensi 4,5\%, diare yang dapat disebabkan oleh Shigella dysentriae dan Escherichia coli memiliki insiden dan prevalensi pada semua umur adalah 3,5 \% dan 7,0 \% (Fauziah, 2015). Kasus demam typhoid yang disebabkan oleh Salmonella typhi di Indonesia pada tahun 2012 ada 600 - 1,3 juta setiap tahunnya dengan lebih dari 20.000 kematian (WHO, 2012). Proteus mirabillis merupakan salah satu penyebab dari infeksi saluran kemih (ISK) sebesar 0,7-0,9\% (Novard et al., 2019). Pseudomonas aeruginosa menimbulkan penyakit ISK, dan infeksi pada luka bakar dengan angka fatalitas mencapai 50\% di RSUD Dr. Soedarso Pontianak tahun 2011-2013 (Lutpiatina, 2017). Staphylococcus aureus menjadi penyebab penyakit kulit dan infeksi jaringan lunak yang paling utama. Bakteri ini menjadi penyebab infeksi kulit sebesar 7-10\% (Novard et al., 2019).

Timbulnya resistensi pada beberapa antibiotik telah menyebabkan kegagalan dalam penanggulangan berbagai jenis penyakit infeksi, sehingga perlu dicari alternatif antibakteri baru. Pengembangan alternatif pengobatan dilakukan dengan menggunakan ekstrak tanaman obat sebagai sumber potensi obat baru karena lebih murah, lebih mudah didapat, dan mempunyai efek samping yang relatif lebih rendah (Mustapha dan Hafsat, 2007).

Sengon memiliki senyawa fitokimia. Senyawa ini dikenal sebagai senyawa metabolit sekunder yang diduga memiliki aktivitas antibakteri. Menurut Rumidatul et al., (2018) hasil uji fitokimia menunjukkan bahwa senyawa metabolit sekunder yang terdapat pada kulit ranting Sengon dengan pelarut $\mathrm{n}$-heksana di antaranya adalah fenolik, flavonoid, terpenoid dan steroid sedangkan menggunakan pelarut metanol juga 
terdapat senyawa saponin dan tanin.

Penelitian ini bertujuan untuk mengetahui aktivitas antibakteri ekstrak kulit ranting Sengon dengan pelarut n-heksana dan metanol terhadap Shigella dysentriae, Klebsiella pneumoniae, Escherichia coli, Salmonella typhi, Staphylococcus aureus, Pseudomonas aeruginosa, dan Proteus mirabilis. Hasil penelitian ini diharapkan memberikan informasi manfaat ekstrak kulit ranting Sengon pelarut metanol dan n-heksana mampu menghambat bakteri uji. Serta dapat sebagai alternatif antibiotik untuk penyembuhan penyakit infeksi.

\section{METODE}

Penelitian ini dilakukan di Laboratorium Mikrobiologi Institut Kesehatan Rajawali pada bulan Februari 2020. Penelitian ini bersifat eksperimen. Sampel yang digunakan adalah ekstrak kulit ranting Sengon dengan pelarut metanol dan n-heksana.

Penelitian ini diawali dari identifikasi bakteri uji, kurva pertumbuhan bakteri, dan uji aktivitas antibakteri ekstrak kulit ranting Sengon dengan pelarut metanol terhadap S. dysentriae, K. pneumoniae, E. coli, $S$. typhi dan pelarut n-heksana terhadap $S$. aureus, $P$. aeruginosa, $P$. mirabilis menggunakan metode Kirby Bauer. Konsentrasi ekstrakyang digunakan yaitu 9\%, 9,5\%, 10\%, 10,5\% dan $11 \%$.

\section{Pembuatan ekstrak}

Metode yang digunakan dalam pembuatan ekstrak senyawa bioaktif dari kulit ranting sengon adalah metode maserasi dengan ekstraksi bertingkat yang telah dimodifikasi (Rumidatul et al, 2018). Ekstraksi bertingkat dilakukan secara berturut - turut dimulai dengan pelarut non polar (n-heksana) kemudian dengan pelarut polar (metanol), dengan demikian akan diperoleh ekstrak kasar yang mengandung senyawa polar dan non polar.

Sampel yang telah dihancurkan ditimbang sebanyak 50 gram dan dimasukkan dalam erlenmeyer kemudian dimaserasi dengan pelarut n-heksana $150 \mathrm{~mL}$ (perbandingan 1:3 (w/v) selama 3x24 jam. Setelah $3 \times 24$ jam, sampel yang direndam tersebut disaring menggunakan kertas saring menghasilkan residu dan filtrat. Selanjutnya filtrat dievaporasi menggunakan rotary evaporator, sehingga diperoleh ekstrak kulit ranting sengon dengan pelarut n-heksana. Sedangkan, untuk residu dimaserasi kembali dengan metanol selama 3x24 jam. Setelah 3x24 jam, sampel disaring menggunakan kertas saring menghasilkan residu dan filtrat. Filtrat dievaporasi menggunakan rotary evaporator, sehingga diperoleh ekstrak kulit ranting sengon dengan pelarut metanol.

\section{Pembuatan variasi konsentrasi ekstrak}

Ekstrak kulit ranting sengon dibuat variasi konsentrasi 9\%, 9,5\%, 10\%, 10,5\% dan 11\%. Pembuatan serial pengenceran dengan cara ekstrak kulit ranting sengon stok awal sebagai $100 \%$ sebanyak $1,1 \mathrm{ml}$ dilarutakan dalam 8,9 ml masing - masing metanol dan $\mathrm{n}$ - heksana. Konsentrasi yang diperoleh dari langkah tersebut adalah $11 \%$. Selanjutnya dibuat serial pengenceran sehingga diperoleh variasi konsentrasi 9\% sampai $11 \%$.

\section{Identifikasi bakteri uji}

Identifikasi dilakukan secara makroskopik dan mikroskopik. Makroskopik dengan mengamati bentuk, warna, tepi, dan permukaan morfologi koloni pada medium NA yang diinkubasi pada suhu $37^{\circ} \mathrm{C}$ selama 24 jam. Mikroskopik dengan metode pewarnaan Gram dan morfologi sel.

\section{Kurva pertumbuhan bakteri}

Subkultur bakteri uji ke dalam medium NB Simpan biakan dalam inkubator dengan suhu $37{ }^{\circ} \mathrm{C}$. Setiap 3 jam biakan dipindahkan sebanyak $2 \mathrm{~mL}$ ke dalam kuvet untuk diukur absorbansi pada panjang gelombang $600 \mathrm{~nm}$ dengan spektrofotometri. Pengukuran terus dilakukan sampai bakteri berada dalam fase kematian yang ditandai dengan adanya penurunan absorbansi.

\section{Uji aktivitas antibakteri}

Celupkan swab steril pada suspensi bakteri yang telah distandarisasi Mc. Farland 0,5\%. Inokulasikan pada medium NA dengan cara menggoreskan swab pada permukaan medium dengan rata, biarkan selama 5 menit sampai mengering. Ekstrak uji dengan masing- masing konsentrasi diambil sebanyak $20 \mu 1$ lalu 
diteteskan pada kertas cakram, kemudian diletakkan di atas media inokulum. Diinkubasi selama 24 jam pada suhu $37^{\circ} \mathrm{C}$. Sebagai perbandingan, digunakan kertas cakram yang ditetesi akuades untuk kontrol negatif dan kontrol positif cakram kloramfenikol $30 \mu \mathrm{g} /$ disk. Aktivitas antibakteri ditunjukan dengan terbentuknya zona bening di sekitar cakram. Pengukuran diameter zona bening menggunakan jangka sorong dilakukan dengan tiga kali ukur secara diagonal selanjutnya direratakan.

\section{HASIL}

Pengamatan identifikasi bakteri uji menggunakan pewarnaan Gram ditunjukkan pada Tabel 1. Berdasarkan Tabel 1 morfologi sel S. dysentriae, S. typhi, K. pneumoniae, E. coli, P. aeruginosa dan $P$. mirabilis menunjukan bentuk sel basil (batang) dan hasil pewarnaan merah, Gram negatif. Sedangkan $S$. aureus menunjukkan morfologi sel kokus (bulat) bergerombol seperti buah anggur.

Kurva pertumbuhan bertujuan untuk mendapatkan waktu optimum fase logamitrik. Fase logamitrik merupakan masa pertumbuhan bakteri mencapai maksimum, sehingga cocok untuk pengujian bakteri. Waktu pengambilan koloni pada medium kultur untuk diujikan pada ekstrak Sengon dipilih ketika pertengahan fase log. Hasil waktu pengambilan $S$. dysentriae dan E.coli yaitu jam ke-15, K. Pneumoniae dan $S$. typhi jam ke-18, P. mirabilis jam ke-21, P. aeruginosa jam ke- 12, dan S. aureus jam ke-6. Hasil kurva tumbuh bakteri dapat dilihat pada Tabel 2 .

Hasil uji aktivitas antibakteri ditunjukkan dengan adanya zona bening. Berdasarkan Gambar 1, hasil uji aktivitas antibakteri ekstrak kulit ranting Sengon dengan pelarut metanol terhadap $S$. dysentriae menghasilkan diameter zona bening yaitu $4 \mathrm{~mm}$ (11\%), $2 \mathrm{~mm}$ (10,5\%), 1,3 mm (10\%), $1 \mathrm{~mm}(9,5 \%)$. Zona bening S. typhi dan E. coli pada konsentrasi $11 \%$ dan $10,5 \%$ pada $S$. typhi yaitu 3,3 mm; $1,7 \mathrm{~mm}$ dan zona bening pada $E$. coli yaitu $1,7 \mathrm{~mm}$ dan $1 \mathrm{~mm}$. Pada $K$. pneumoniae tidak ditemukan adanya zona bening. Adapun ekstrak kulit ranting Sengon dengan pelarut n-heksana terhadap P. mirabilis menunjukkan adanya zona bening pada konsentrasi $11 \%$ yaitu $2,7 \mathrm{~mm}$ dan $10,5 \%$ yaitu $2 \mathrm{~mm}$. Sedangkan pada $P$. aeruginosa dan $S$. aureus tidak terdapat zona bening.

Tabel 1. Hasil identifikasi bakteri uji

\begin{tabular}{|c|c|c|c|c|}
\hline No & Jenis Bakteri & Morfologi Koloni & Morfologi Sel & Hasil Pewarnaan \\
\hline 1 & Shigella dysentriae & $\begin{array}{l}\text { Berbentuk bulat, berwarna } \\
\text { putih, elevasi konveks, } \\
\text { dan tepian halus }\end{array}$ & Basil & $\begin{array}{l}\text { Merah, Gram } \\
\text { negatif }\end{array}$ \\
\hline 2 & $\begin{array}{c}\text { Klebsiella } \\
\text { pneumoniae }\end{array}$ & $\begin{array}{l}\text { Berbentuk bulat, elevasi } \\
\text { konveks, tekstur mukoid }\end{array}$ & Basil & $\begin{array}{l}\text { Merah, Gram } \\
\text { negatif }\end{array}$ \\
\hline 3 & Salmonella typhi & $\begin{array}{l}\text { Berbentuk bulat, berwarna } \\
\text { putih, elevasi konveks, } \\
\text { dan tepian halus }\end{array}$ & Basil & $\begin{array}{l}\text { Merah, Gram } \\
\text { negatif }\end{array}$ \\
\hline 4 & Escherichia coli & $\begin{array}{c}\text { Berbentuk bulat, berwarna } \\
\text { putih putih, elevasi } \\
\text { konveks, tekstur halus }\end{array}$ & Basil & $\begin{array}{l}\text { Merah, Gram } \\
\text { negatif }\end{array}$ \\
\hline 5 & $\begin{array}{l}\text { Pseudomonas } \\
\text { aeruginosa }\end{array}$ & $\begin{array}{c}\text { Bentuk bulat, kasar, tepian } \\
\text { tak rata, menjalar, pigmen } \\
\text { hijau }\end{array}$ & Basil & $\begin{array}{l}\text { Merah, Gram } \\
\text { negatif }\end{array}$ \\
\hline 6 & Proteus mirabilis & $\begin{array}{l}\text { Bentuk bulat, } \\
\text { cembeung, tepian tak rata, } \\
\text { menjalar }\end{array}$ & Basil & $\begin{array}{l}\text { Merah, Gram } \\
\text { negatif }\end{array}$ \\
\hline 7 & phylococcus aureus & $\begin{array}{l}\text { Bentuk bulat, halus, tepian } \\
\text { rata, tidak menjalar }\end{array}$ & Kokus & Ingu, Gram positif \\
\hline
\end{tabular}

Tabel 2. Hasil kurva pertumbuhan bakteri

\begin{tabular}{cccccc}
\hline \multirow{2}{*}{ Jenis Bakteri } & \multicolumn{4}{c}{ Fase (jam ke-) } & Waktu \\
& Lag & Log & Stasioner & Kematian & optimum \\
\hline
\end{tabular}




\begin{tabular}{cccccc}
\hline S. dysentriae & $0-3$ & $9-24$ & $27-36$ & 39 & 15 \\
K. pneumoniae & $0-3$ & $9-27$ & $30-39$ & $42-48$ & 18 \\
E. coli & $0-3$ & $9-24$ & $27-39$ & $42-48$ & 15 \\
S. typhi & $0-3$ & $6-24$ & $27-36$ & 39 & 18 \\
P. aeruginosa & $0-3$ & $6-24$ & $27-33$ & 36 & 12 \\
P. mirabilis & $0-12$ & $15-24$ & $27-39$ & 42 & 21 \\
S. aureus & 0 & $3-21$ & $24-36$ & 39 & 6 \\
\hline
\end{tabular}

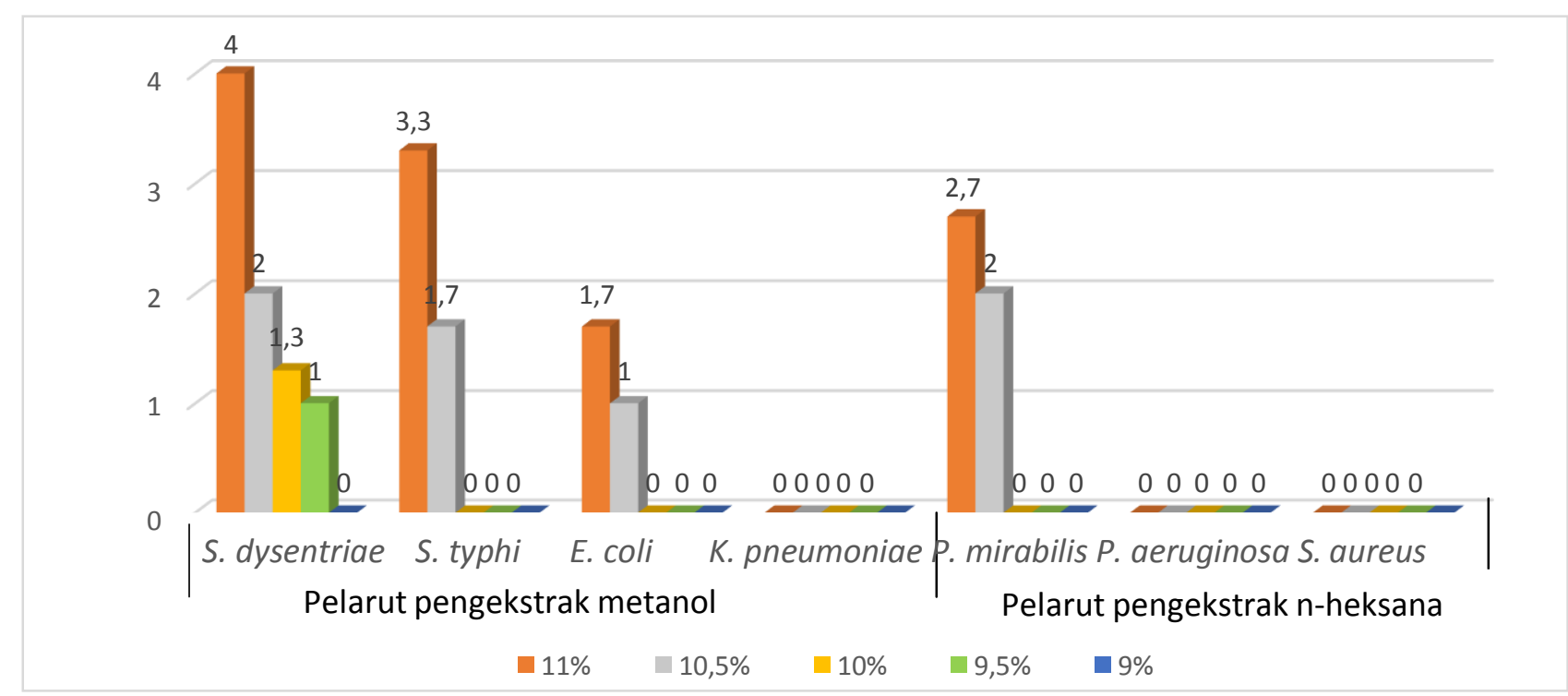

Gambar 1. Diameter zona bening ekstrak kulit ranting Sengon dengan pelarut metanol dan $\mathrm{n}$-heksana terhadap bakteri uji.

\section{PEMBAHASAN}

Identifikasi bakteri dilakukan untuk memastikan bakteri uji yang digunakan murni tanpa adanya kontaminasi. Hasil pewarnaan Gram menunjukkan perbedaan dua kelompok yaitu bakteri Gram negatif terwarnai merah oleh safranin dan bakteri Gram positif terwarnai ungu oleh kristal violet. Hal tersebut

karena Gram positif memiliki lapisan dinding peptidoglikan tebal sehingga ketika didehidrasi dengan alkohol, pori dinding sel akan menutup dan menjaga kompleks kristal violet. Sedangkan Gram negatif didominasi lipopolisakarida yang akan tercuci oleh alkohol sehingga kristal violet akan hilang danterwarnai dengan pewarnaan kedua, safranin (Rahmawati, 2015).

Kurva pertumbuhan bakteri bertujuan untuk mendapatkan waktu optimum fase logamitrik. Fase logamitrik merupakan masa pertumbuhan bakteri mencapai maksimum, sehingga cocok untuk pengujian bakteri. Suatu zat antimikroba ketika akan diuji aktivitas antimikrobanya, maka mikroba uji yang digunakan harus dalam keadaan fase aktif pembelahan sel dengan laju konstan (Handayani, 2015). Kurva pertumbuhan terdapat empat fase yaitu fase adaptasi (lag), fase eksponensial (log), fase stasioner dan fase kematian. Fase lag merupakan penyesuaian mikroorganisme pada lingkungan baru sehingga pertumbuhan sel tidak maksimal. Fase eksponesial (log) mulai mengadakan perubahan bentuk dan meningkat jumlahnya sehingga kurva meningkat dengan tajam. Kecepatan pertumbuhan bekteri dipengaruhi oleh lingkungan, kandungan nutrien dalam medium, tempratur, kadar oksigen, cahaya. Fase stasioner merupakan berkurangnya zat- zat makanan dalam pembenihan atau penumpukan hasil metabolisme beracun menyebabkan pertumbuhan terhenti, sehingga gambaran grafik mendatar. Fase kematian merupakan akhir dari suatu kurva, dimana jumlah individu secara tajam menurun. Matinya sel-sel mikroba disebabkan habisnya zat makanan dan menumpuknya zat beracun (Pratiwi, 2008). 
Hasil aktivitas antibakteri ditunjukkan dengan adanya zona bening disekitar cakram. Berdasarkan Gambar 1, pengujian ekstrak kulit ranting Sengon dengan pelarut metanol terhadap S. dysentriae, E. coli, dan S. typhi menunjukan adanya aktivitas antibakteri, namun tidak terdapat aktivitas antibakteri terhadap $K$. pneumoniae. Hal tersebut diduga karena faktor sifat organisme $K$. pneumoniae yang mempunyai struktur dinding sel lebih tebal yaitu adanya lapisan kapsul polisakarida sehingga metabolit sekunder tidak mampu merusak bagian dinding sel dan tidak terjadi penghambatan.

Pengujian ekstrak kulit ranting Sengon dengan pelarut n-heksana terhadap $P$. mirabilis menunjukan adanya aktivitas antibakteri tetapi tidak pada S.aureus dan $P$. aeruginosa. Hal tersebut dipengaruhi oleh faktor virulensi yang dimiliki $P$. aeruginosa dan S. aureus. Menurut penelitian Boyd (2017) S. aureus adalah bakteri patogen utama penyebab supuratif infeksi, yang dapat memproduksi $\beta$-laktamase, sehingga dengan mudah dapat resisten terhadap golongan antibiotik $\beta$-laktam seperti penisilin. Sedangkan $P$. aeruginosa mempunyai plasmid yang resisten terhadap antibiotik dan mampu mentransfer gen-gennya melalui transduksi dan konjugasi bakteri. P. aeruginosa memiliki kemampuan resistensi secara alami terhadap antibiotik yaitu kecenderungan untuk berkolonisasi pada permukaan-permukaan membentuk suatu biofilm mengakibatkan sel- selnya tahan terhadap antibiotik (Tolan, 2008).

Faktor lainnya yaitu kandungan senyawa metabolit sekunder yang berpotensi sebagai antibakteri pada ekstrak tidak mengandung senyawa motabolisme murni atau kadarnya sangat sedikit sehingga tidak memiliki efek menghambat pertumbuhan $K$. pneumoniae, $P$. aeruginosa dan $S$. aureus.

Perbandingan pelarut pengekstrak metanol dan n-heksana dapat dilihat pada Gambar 1, dimana pelarut metanol memiliki diameter zona bening yang lebih besar. Berdasarkan penelitian Rumidatul et al., (2018) kandungan senyawa metabolit sekunder kulit ranting Sengon yang diekstraksi menggunakan n-heksana menghasilkan fenolik, flavonoid, terpenoid dan steroid. Sedangkan ekstraksi dengan pelarut metanol juga terdapat senyawa saponin dan tanin. Pelarut metanol menghasilkan kandungan senyawa metabolit sekunder lebih banyak dibandingkann-heksana sehingga mempengaruhi aktivitas antibakteri.

Secara keseluruhan dapat dilihat bahwa peningkatan diameter zona bening sebanding dengan kenaikan konsentrasi. Hal ini disebabkan tingginya konsentrasi ekstrak berpengaruh pada aktivitas antibakteri dan zona bening yang terbentuk juga semakin besar. Hal tersebut menyatakan bahwa kandungan senyawa antibakteri pada ekstrak berpengaruh pada ukuran zona bening. Tidak terbentuknya zona bening pada konsentrasi tertentu disebabkan oleh kecilnya konsentrasi zat aktif sehingga belum mampu menghambat bakteri.

Aktivitas antibakteri yang ditimbulkan oleh ekstrak kulit ranting Sengon dapat terjadi karena kandungan metabolit sekunder seperti fenolik, flavonoid, terpenoid, steroid, saponin dan tanin. Mekanisme antibakteri senyawa fenolik adalah mengubah permeabilitas membran sitoplasma sehingga terjadi kebocoran bahan-bahan intraseluler, kemudian mendenaturasi dan menginaktifkan protein seperti enzim (Elsas, 2014). Terpenoid dengan cara bereaksi dengan porin (protein transmembran) membentuk ikatan polimer yang kuat sehingga mengakibatkan rusaknya porin (Tiolina, 2017). Steroid berinteraksi dengan membran fosfolipid sel sehingga menyebabkan integritas membran menurun serta morfologi membran sel berubah menyebabkan rapuh dan lisis (Juliatri et al., 2016). Mekanisme flavonoid menghambat sintesis asam nukleat, menghambat fungsi membran sel, dan menghambat metabolisme energi (Rumidatul et al., 2018). Saponin dengan cara menurunkan tegangan pada permukaan yang mengakibatkan terjadinya kebocoran pada sel (Anggraini, 2017). Mekanisme kerja tanin dengan cara melisiskan sel bakteri dengan target pada dinding polipeptida dinding sel bakteri (Juliatri et al., 2016).

\section{KESIMPULAN}

Ekstrak kulit ranting Sengon dengan pelarut metanol memiliki aktivitas antibakteri terhadap $S$. dysentriae, S. typhi, E. coli. Ekstrak kulit ranting Sengon dengan pelarut n-heksana memiliki aktivitas antibakteri terhadap P. Mirabillis. Penelitian selanjutnya disarankan melakukan pemurnian dan identifikasi terhadap senyawa metabolit sekunder yang terkandung dalam ekstrak kulit ranting Sengon dengan pelarut metanol dan n-heksana.

\section{REFERENSI}

Anggraini, AM. (2017). Uji Efektivitas Ekstrak Daun Rambutan (Nephelium Lappaceum L) Terhadap Pertumbuhan Candida albicans. Skripsi: Fakultas Kedokteran Gigi. Universitas Muhammadiyah Semarang. 
Boyd, K. (2017). Back to the basics: communityacquired pneumonia in children. Pediatr Ann. 46: 257-261.

Elsas, MD. (2014). Aktivitas Antibakteri Ekstrak Daun Sengon (Falcataria moluccana (L) Nielsen) Terhadap Bakteri Staphylococcus aureus dan Escherichia coli. Skripsi: Fakultas MIPA Institut Pertanian Bogor.

Fauziah, I. (2015). Aktivitas Antimikroba Ekstrak N-Heksan Daun Jatropha gossypifolia Linn Dengan Metode Bioautografi Terhadap Escherichia coli.Skripsi: Fakultas Ilmu Kesehatan Universitas Muhamadiyah Malang.

Handayani, PN. (2015). Isolasi, Seleksi, dan Uji Aktivitas Antimikroba Kapang Endofit dari Daun Tanaman Jamblang (Syzgium cumini L.) Terhadap Escherichia coli, Pseudomonas aeruginosa, Bacillus subtilis, Staphylococcus aureus, Candida albicans, dan Aspergillus niger. Skripsi: Fakultas Kedokteran dan Ilmu Kesehatan. UIN Syarif Hidayatullah Jakarta.

Juliatri, Waworuntu O, Sapara T. (2016). Efektivitas Antibakteri Ekstrak Daun Pacar Air (Impatiens balsamina L.) Terhadap Pertumbuhan Porphyromoas gingivalis. Jurnal Ilmiah Farmasi UNSRAT; 5(4):10- 18.

Lutpiatina, L.(2017). Cemaran Staphylococcus aureus dan Pseudomonas aeruginosa Pada Stetoskop Di Rumah Sakit. Jurnal Teknologi Laboratorium. Sep;6(2):61-6

Mustapha, Y. \& Hafsat, S. (2007). Antibacterial Activities of Anacardium occidentale (L.) Leaf Extract Against Some Selected Bacterial Isolates, International Journal of Pure and Apllied Sciene; 1(1), 40-43.

Novard, MFA; Suharti, N; dan Rasyid. (2019). Gambaran bakteri penyebab infeksi pada anak berdasarkan jenis specimen dan pola resistensinya di laboratorium RSUP Dr. M. Djamil Padang tahun 2014-2016. Jurnal kesehatan andalas; 8(2):26-32.

Pratiwi, ST. (2008). Mikrobiologi Farmasi.Jakarta: Erlangga

Rahmadian CA, Ismail, Abrar M, Erina, Rastian, dan Fahrimal Y. (2008). Isolasi dan Identifikasi bakteri Pseudomonas $s p$ pada Ikan Asin di tempat Pelelangan Ikan Labuhan Haji Aceh Selatan. JIMVET EISSN; 2(4):493-502.

Rahmawati, M. (2015) Uji Aktivitas Antimikroba Ekstrak Etanol dan Air Rimpang Pacing (Costus spiralis) Terhadap Bakteri Escherichia coli, Shigella dysenteriae, Salmonella typhimurium, Bacillus subtilis, Staphylococcus aureus Serta Fungi Candida albicans. Skripsi: Fakultas Kedokteran dan Ilmu Kesehatan UIN Syarif Hidayatullah Jakarta.

Rumidatul A, Aryantha INP, dan Sulistyawati E. (2018). Potensi Medik Metabolit Tanaman Sengon (Falcataria moluccana) Yang Terserang Penyakit Karat Tumor. Institut Teknologi Bandung.

Tiolina, ND. (2017). Pengujian aktivitas antibakteri ekstrak kulit ranting Sengon (paraserianthes falcataria) berumur 1-2 tahun dengan pelarut N- heksan terhadap Staphylococcus aureus, Salmonella thypi, Shigella sp, dan Klebsiella sp. Skripsi: Program Studi Analis Kesehatan. Institut Kesehatan Rajawali Bandung.

Tolan, R.W. (2008). Pseudomonas aeruginosa infection. [cited 2020 Jul 29]; Available from: URL: http://www.emedicine.com/ped/topic 2704.htm

WHO. (2012). Global Report for Research on Infectious Diseases of Poverty. [cited 2019 Des 31]; Available from: URL:https://www.who.int/tdr/capacit y/global report/en/ 